\title{
Revolutions, Treaties, and State Succession
}

International law does not generally count revolutions among those events that justify termination of existing treaty ${ }^{2}$ rights and obligations. ${ }^{3}$ This view is said-in the few instances when the question is squarely faced-to derive from the need for state continuity in international affairs and from the general irrelevance of changes in government to questions of international law. ${ }^{4}$ The principle rebus sic stantibusthat treaties terminate upon "vital" changes in circumstance-is not applied to revolutions. ${ }^{5}$

1. For discussion of the concept of a revolution, see p. 1682-83 infra.

2. The concept of a treaty is not a clear one, particularly in the United States. In the United States Constitution, art. II, § 2, the term "treaty" is used for international agreements ratified by the President with the advice and consent of the Senate, two thirds of the Senators having to concur therein. The phrase "cxecutive agrecment" is used in common parlance to describe all international agreements which become binding on the United States in any other way (usually through the signature of the President). The distinction has never found a legal base either in international law or in United States domestic law. The State Department has taken the position that "in international law ... treaties and executive agreements are alike, and both constitute equally binding obligations on the Nation." Letter from Under Secretary of State Webb to Secretary of Defense Johnson, Jan. 17, 1950, in U.S. DeP't of State, The Law of Treaties 224 (1950). For a debate of the policy issues underlying the distinction, see Borchard, Shall the Execulive Agreement Re. place the Treaty?, 53 YALE L.J. 664 (1914), and MCDougal \& Lans, Trealies and Congressional-Executive or Presidential Agreements: Interchangeable Instruments of Nalional Policy (pts. 1-2), 54 Yale L.J. 181, 534 (1945). See S. Crandald, Treaties, Tueir Mikinc AND ENFORCEMENT (2d ed. 1916) for a discussion of how treaties are made.

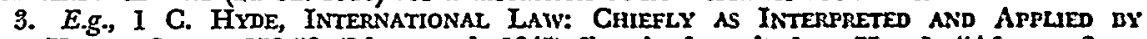
THE UNITED STATES 158-59 (2d rev. ed. 1945) [hereinafter cited as HyDE]: "After a State has come into being, its obligations in relation to the outside world are not aftected in consequence of internal changes which may be undergone." Even more specific is $A$. Ross, A TEXTBOoR of INTERNational LAw 134 (1947) [hercinafter cited as Ross]: "It is generally acknowledged that an internal revolution in the government of a state does not involve any change in the international status of the state." The remaining works state that changes in government are not treaty-terminating and imply that revolutions are changes in government alone: I J. MOORE, Digest OF INTERNATIONAL LAW 249 (1900); 5 G. HACKW'ORTH, Digest OF INTERNATIONAL LAW 360 (1944-45) [hereinafter cited as HAckwormi]; Law of Treaties, art. 24, in HARVARD ReSEARCH IN INTERNATIONAL LAw, 29 Aar. J. INT'L LAw 1044-55 (Supp. 1935) [hereinafter cited as HaRvard REsearch]; A. MíNAIR, THE LAW of Treaties G63-76 (2d ed. 1961) [hereinafter cited as MICNAIR]; 2 HYDE 1528. For the present Sovict view, see J. Triska \& $R$. Slusser, The Theory, Law, ANd Policy of Soviet Treaties 142-55 (1962) [hereinafter cited as TrISRA \& SLuSSER]. The Sovict view has changed since 1917 and is now in accord with the prevailing view. See the Soviet English-language textbook, INTERNATIONAI LAw, at 281 (N.D.).

4. See authorities cited note 3 supra.

5. None of the major treatises on international law is of the vicw that rebus sic stantibus is a sufficient ground for terminating or modifying a treaty upon the occurrence of a revolution. Most assume, however, possibly without having adverted to the matter, that the rebus doctrine is not even relevant to the question of whether occurrence of a revolution affects treaties. This assumption is manifested in the fact that these treatises deal with the effect of revolutions on treaties in wholly different chapters, or subsections, from the chapters in which they deal with the rebus doctrine. This is true of $1 \mathrm{~L}$. Oppenuen, INTERNANATIONAI LAw (8th ed. H. Lauterpacht 1955) [hereinafter cited as Orpevileis], MraNain. Hackworth, and HYDE. See also W. Bishop, International IAw: Cases aNd Miatenuls (2d ed. 1962) [hereinafter cited as BLsHOP]. HARvard REsearci deals with the two questions in separate articles, Article 24 (Effect of Governmental Changes) and Article 28 (Rebus Sic 
The denial of treaty-terminating force ${ }^{\mathfrak{b}}$ to revolutions has frequently hurt the international legal system. Revolutionary governments, condemned as outlaws when they repudiated the treaties of their predecessors, have been denied recognition, and thus cut off from the world community. The result has been to undermine the acceptance of international law-a law which lives on acceptance. ${ }^{7}$

In addition to its practical failings, the rejection of the claim that revolutions should terminate treaties ignores established policies of international law. Some of these policies rest upon recognized principles of fairness, principles particularly important in a system with a short supply of case law and other authority. ${ }^{8}$ Others are based upon the peculiar imperfections of international law as a means for ordering behavior. Taken together, these policies outline a general doctrine of treaty termination which unifies many of the treaty-terminating changes hitherto treated as conceptually discrete. ${ }^{0}$

Stantibus), though the end of Article 24 contains reference (at 1055) to Article 28's possible application.

6. The phrase "treaty-terminating force" is used here to cover situations, conditions, or occurrences which constitute grounds in international law for either terminating or modifying a treaty. Treaty-terminating force may result from such situations, conditions, or occurrences only after a specific procedure has been complied with.

7. See p. 1678-81 and note 43 infra.

8. The statute of the International Court of Justice, for instance, bids it apply, as a source of law, "the general principles of law recognized by civilized nations." 1.C.J. STAT. art. 38, para. $1(c)$. This has always been interpreted to include general principles of equity:

What are widely known as principles of equity have long been considered to consti-

tute a part of international law, and as such they have often been applied by inter-

national tribunals. [Authorities omitted.] A sharp division between law and equity,

such as prevails in the administration of justice in some States, should find no place in

international jurisprudence. ... .

The Court has not been expressly authorized by its Statute to apply equity as dis. tinguished from law. Nor, indeed, does the Statute expressly direct its application of international law. . . Article 38 of the Statute expressly directs the application of "general principles of law recognized by civilized nations," and in more than one nation principles of equity have an established place in the legal system. . . . It must be concluded, therefore, that under Article 38 of the Statute, if not independently of that Article, the Court has some freedom to consider principles of equity as part of the international law which it must apply.

Diversion of Water from the River Meuse Case, [1937] P.C.I.J., ser. A/B, No. 70 (concurring opinion of Hudson, J.). Hudson's remarks go to interpretation of the statute of the Permanent Court of International Justice, rather than the statute of the present International Court of Justice. But the two statutes are substantially the same and the history of the two courts is closely linked. See BIsHop 62; Jalet, The Quest for the General Principles of Law Recognized by Civilized Nations-A Study, 10 U.C.L.A. L. REv. 1041 (1963). Again and again, international tribunals have fallen back on what seems fair or equitable to the parties as a means of deciding a case. A good example is the Cayuga Indians Case (Great Britain v. United States), 6 U.N.R.I.A.A. 187 (1926), reprinted in 20 AM. J. 1NT'L L. 574 (1926).

9. This doctrine would not inappropriately be called rebus sic stantibus, despite the fact that the present rebus doctrine is usually conceived in a quite different manner and is fairly controversial. Two problems surround the present rebus doctrine. First, discussions of it usually never get beyond saying that it somehow expresses the intentions of the parties to a treaty. E.g., 2 HYDE 1523-27. Here it seems best simply to realize that the decision to allow abrogation of a treaty because circumstances have changed is morc likc 
I.

In international law, a state is bound by treaties only so long as it remains the same state. A fairly well-established subcategory of international law- the law of state succession ${ }^{10}$ - provides for the termination of treaties after a change of state identity. Several sorts of events arguably change the identity of a state:

(1) Increase in territory through purchase or conquest;

(2) Loss of territory through sale, secession, or foreign conquest; ${ }^{11}$

(3) Coming under the suzerainty of another state; ${ }^{12}$

(4) Federation (as opposed to real union);

construction than interpretation, for the crucial element in the decision is the nature of the change and its substantive consequences rather than direct information about what the parties intended. Second, rebus sic stantibus is presently conceived as a residual doctrine, one to be applied only if other well-established treaty-terminating grounds cannot be found. See note 5 supra. This continually puts the doctrine out of the range of paradigms which could be useful in tying it down. It seems better to use the doctrine as a general principle, of which all the well-established treaty-terminating changes are instances. The earlier version of McNair's book did something very like this (see that version, published in 1938, at 376-449), but the idea was dropped for the latest edition. See MraNan 681-89. The reason for this variation between the two editions does not appear. It is signifieant to note, however, that between the two editions the rebus doctrine was appealed to by both China and Cuba as a justification for treaty-termination after revolutions in each of those two countries. Finally, a good example of the continuing failure to supply a proper or eren a new analysis of rebus sic stantibus is found in the reports of the International Law Commission. The Commission, an agency of the United Nations, is currently working on its Draft Articles of the Law of Treaties. See Official Documents, 61 Aar. J. InT'L L. 248, 428-35 (1967) [hereinafter cited as I Aw CoMinission].

10. D. O'Connell, The LAW of State Succession (1956) [hereinafter cited as O'ConNEII]. O'Connell unfortunately is committed to the proposition that "personality" is the key to the problem of State succession ... the consequences of change of sovereignty vary according to the extent to which such personality is affected." This is unfortunate beasuse the proposition is a tautology: to argue that state succession depends on degree of personality lost or gained is simply to restate the question at issue.

11. O'CONNEIL 31: "A State may be fractionalized and jet ... [i]ts treaty obligations survive with it unless, on interpretation, it is found that the diminution of territory is a terminating factor. The successor State does not inherit any of the obligations of such treaties, be it a cessionary State or a new State commencing life by secession from the old." See MaNAIR 633-38. O'Connell limits his statement to personal treaties, separating these from dispositive treaties (boundary treaties, international servitudes, and capitulstions). The distinction is controversial. See $0^{\prime}$ CoNNerL $49-53$, especially $52 \mathrm{n} 3$, for a list of authors who disagree with him on the distinction. For further discussion on the matter, see p. 1684-86 infra.

12. O'CONNELL 28: "[A] State coming under the protection or suzerainty of another remains obliged by such treaties as are not inapplicable in the new circumstances." See MCNAIR 622-29.

13. When a State becomes a member of a Federal State, the future position of the treaties of the former State depend [sic] in principle upon the Constitution of the

Federal State. If the provisions of the Constitution are such that the member States

possess no international personality and no treaty-making capacity-the position in the

United States of America-then the treaties of the former State... are cntirely terminated.

McNAIr 629. See O'Connent 26-28, 36-39 for a more complete discussion of the various possibilities. Cases where the constitution of the federal state does not provide for independent treaty-making capacity are known as cases of real or personal union; the paradigm example is that of Texas, which joined the United States in 1845. 
(5) Independence; ${ }^{14}$

(6) State extinguishment through subjugation or annexation, political dismemberment, or real union. ${ }^{15}$

Present doctrine, however, recognizes only events within the last two categories-extinguishment and independence-as changing state identity and hence treaty-terminating.

When a state is extinguished, it is thought unfair to hold the state which succeeds to control over the territory to bargains made by its predecessor. The successor-a "different state" from the one extinguished-may have different interests and affinities in its international affairs, and should be able to pursue those interests free from obligations taken on by others. Similarly, a newly independent state can free itself from any of the treaties of its former sovereign; the law assumes that these treaties were concluded with the often inconsistent interests of the parent state in mind. ${ }^{16}$ In cases of both extinguishment and independence, the treaty partner of the "changed" state is also released from its obligations. It bargained neither with nor for the newly independent state (or the successor to the extinguished state), and no reason exists why its interests with respect to such a state should be the same as with respect to its predecessor.

Revolutionary governments have often argued that they constitute newly independent states or that they are the successors to states now

14. McNaIR 601: "[N]ewly established States which do not result from a political dismemberment and cannot fairly be said to involve political continuity with any predecessor, start with a clean slate in the matter of treaty obligations . . . " Both MaNıik and O'CONNELL (at 32-48) add certain qualifications to this statement. The qualifications concern the extent to which the state participated in treaties affecting it before it achicved full independence.

15. J. Brierly, LAw of Nations 153 (6th ed. 1963): "Further, when a State ceases to exist, its treaties generally cease with it." O'CONNELL 16: "There is almost uninimous agreement that personal treaties of a totally extinguished State expire with it." He cites annexation, dismemberment, and real union as examples of extinction.

The following are examples of the extinction of a state. By annexation and/or conquest: Algiers, which was conquered in 1830 by France; Santo Domingo, 1861; Upper Burma, 1885; Madagascar, 1896; Hawaii, 1898; Transwaal Republic and Orange Free State (the IBoer Rc. publics), 1900; Korea, 1910; Austria, 1938. By political dismemberment: Colombia, 1829. 1836; Sweden-Norway, 1905; Austria-Hungary; 1918. See MaNsIR 593-617; O'CoNNELL 17-24.

16. The rule is modified by the considerations discussed at p. 1684-86 infra. For a fuller discussion, see INTERNATIONAL LAw Association, THE EFFECr OF INDEPENDENCE ON Treatres (1965). The only exception to the rule occurs when it can be shown that the newly independent state did in fact exercise some degree of self-control in the period immediately preceding independence. Such a situation occurred, for example, in thic case of India, which as early as 1919 acquired a degree of self-government. Here, of course, the policy of not holding parties to agreements in which they did not participate, or over which they have no control, does not apply, and consequently the party is held. Sec O'CoNNELL 32-48. 
extinguished. ${ }^{17}$ While rejected by writers, this reasoning has force. The revolutionary leaders had no role in concluding the prior treaties. Indeed, the foreign policy, or even a particular treaty, of the predecessors may have caused or catalyzed the revolution. ${ }^{18}$ The revolutionaries have come to power with policies and a conception of the national interest radically different from that of the deposed regime. Their revolution has repudiated the authority which ratified the treaties: ${ }^{10}$ the revolution marks, in McNair's phrase, a "break in legal continuity" with the past. ${ }^{20}$

Independence, in fact, can be considered a special case of revolution. A revolutionary movement which succeeds only partially, winning control over only part of the territory of a state, will be regarded under international law as a new state, free from the rights and obligations

17. For example, the Soviet Union argued in 1922 that:

The revolution of 1917 , having completely destroyed all the old relationships, cconomic, social and political, and having replaced the old social order (class divisions) by the new social order, the sovereignty of an insurgent people, tuming over the power of the Russian State to a new social class, did by this fact break the succession of thace civil obligations which were component elements of the cconomic relations of the social order now extinct.

Statement by the Soviet Delegation at Geno3, April 20, 1922, ciled in Korovin, Soviel Treaties and International Law, 22 ANr. J. INT'L L. 753, 763 (1928). Korovin, who was a professor of international law at the University of Moscow, interpreted the angument in this way: "Thus in a sense the Soviet Doctrine appears to be an extension of the principle of rebus sic stantibus, while at the same time limiting its ficld of application by a single circumstance-the social revolution." Id.

A more recent example concerns Cuba. In a television intervicw on $28 \mathrm{March} 1960$, Fidel Castro said, commenting on U.S. Secretary of State Christian Herter's remark that "all Latin American countries are interested in [Cuba's turning communist] because they have a compact with regard to Communist Governments among themselves":

That is the way they are threatening to have the Latin-American republics gang up

on us by invoking the Treaty of Rio de Janeiro, which we do not consider to be binding on us since it was not signed by the Revolution.

N.Y. Times, Mar. 31, 1960, § 1, at 3, col. I.

18. See note 42 infra.

19. If Kelsen's analysis of a legal system is accepted, then by definition a revolution results in a wholly new legal system replacing the old one. This is so because for Kelsen the defining characteristic of each law in the system is the Grundnorm, and when this is replaced by force the whole system goes with it. Only by reference to this Grundnorm is a particular law a law at all. Consequently, upon the occurrence of a revolution:

The laws which, in the ordinary inaccurate parlance, continue to be valid are, from a juristic viewpoint, new laws whose import coincides with that of the old laws. They are not identical with the old laws, because the reason for their validity is different. The reason for their validity is the new, not the old, constitution, and between the two continuity holds neither from the point of view of the one nor from that of the other. Thus, it is never the constitution merely but alwajs the entire legal order that is changed by a revolution.

H. Keisen, General Theory of LAw and State 117-18 (1945). This position, aside from its elusive metaphysical quality, leaves Kelsen unable to distinguish between revolutions and lesser forms of unconstitutional change in society, including coups d'ctat. Indecd Kelsen, id. at 117, wishes to make no such distinction; his forthrightness on the point is admirable, but the difficulty persists. Kelsen is correct, though, in emphasizing the importance of changes in the legal system as a test of a revolution. See p. 1684-86 infra.

20. MaNaIR 673. 
created by prior treaties. ${ }^{21}$ Indeed, "the obvious historical example is that of the United States of America." 22 Yet under existing doctrine, if the revolution is wholly successful and wins the entire territory, the treaties of the old regime will still be binding; to escape prior treaties, apparently, revolutionaries must stop just before they take the whole country.

Arguments of this sort usually meet with the response that they ignore the traditional distinction between a state and its government. Lord McNair states the distinction with Olympian assurance:

It is necessary to remind ourselves from time to time that when we say that a State is a subject of international law . . . we mean the State itself, not its Government. Governments are the agents or representatives of States. ... The statement that, in the eye of the law, the parties to treaties are States, so that treaties remain in force in spite of changes in the form of Governments, is supported by ample textbook authority and is indeed obvious. ${ }^{23}$

21. See MCNAIR 600.06; O'CONNELl 32-36; Triska \& SLusser 162 (using the word "succession" to mean "secession"). Young, The State of Syria: Old or New?, 56 AM. J. INT'L L. 482, 487 (1962): "States which arise through a successful act of sccession or dissolution do not normally inherit the treaty obligations of the state from which they came. ...."

22. Jones, State Succession in the Matter of Treaties, 24 BRTT. Y.B. INT'L L. 360, 366 (1947).

23. McNaIr 668. For other examples, see the authorities cited note 3 supra, Most writers capitalize "state" and "government" in order to lend authority to the distinction.

In this regard, McNair cites a decision of the United States Supreme Court. In The Sapphire, 78 U.S. (11 Wall.) 164 (1870), the Court held that an admiralty action instituted by Napoleon III in respect of a French transport damaged by collision with an American ship was not abated by the conversion of France from a monarchy into a republic. Thic question arose because between decision in the U.S. district court (awarding full damages to the libellant) and hearing on appeal to the Supreme Court, Napoleon III was deposed. The Court said:

The reigning Emperor, or National Assembly, or other actual person or party in power, is but the agent and representative of the national sovereignty. $A$ change in such repre. sentative works no change in the national sovereignty or its rights. . . . A deed to or treaty with a sovereign as such enures to his successors in the government of the country. ...

Id. at 168. MiNair believes these words support his view. McNAIR 670.71.

Admittedly, The Sapphire does involve a revolution, but its holding may be construcd more narrowly than McNair sees it. Specifically, it does not hold that treaties remain unaffected by revolutions. The case did not involve any treaty at all. Morcover, it did not hold that a revolutionary government does not have the right to terminate treatics it finds objectionable. The case did not limit the rights of revolutionary governments in any way, but rather extended those rights to include that of maintaining suits in American courts for damage to ships owned by the present government's predecessor in cases where thic damage was caused by American ships. To be sure, the Court said all this in terms of a distinction between sovereignty and the representatives of that sovereignty, a distinction which lends itself to broad generalizations. But the Court's language does seem limited by the context in which it arose-that of extending a right to sue for damages to a ship paid for: presumably, out of general tax revenues. The idea behind the decision was that there lias been an injury to the people of France and they should not be penalized because they have a new sovereign now. And none of these concepts-injury to the people, right to sue, negligent conduct-have any relevance in the context of treaty termination.

The other case which McNair cites, McNalr at 671, In re Lepeschkin, 49(1) Entscheidungen des Schweizerischen Bundesgerichtes (BGE) 188 (1923) [text in H. Jurccs, 
Behind this conclusion is an argument. If every election, cabinetsweeping, or other change in government personnel terminated treaties, the very reason for concluding treaties-stabilizing expectationswould be defeated. ${ }^{24}$ Obligations would die with statesmen. But this, the argument runs, is what recognition of revolutions as treaty-terminating events would lead to. If revolutionaries can escape from treaties because they have different ideas of the national interest or because they were not consulted when these treaties were concluded, might not any new government leadership make the same claim?25

The argument, while appealing, is specious. Genuine revolutions are rare. ${ }^{26}$ Recognizing them as treaty-terminating will not cause the constant disruption of expectations legitimately feared if normal changes of government were given like effect. Moreover, since revolutionary governments are likely to abrogate some treaties regardless of what international law provides, a rule making such abrogation illegal can promote only a stability of false expectations. Distinguishing between a revolutionary government and a new government with fundamentally new policies admittedly rests partly upon a judgment of degree-the judgment that regular and constitutional changes of government policy and leadership do not generally alter circumstances so drastically from those reasonably foreseeable when the treaty was made that the continued enforcement of the treaty would be unfair.9 The claim is not that all revolutions are "more drastic" than all legal changes of government, but only that the presence or absence of legal continuity between two governments is an identifiable element which

\footnotetext{
A LAw of Nations 931 (1951)], actually implied the opposite of the vicw that the stategovernment distinction is applicable in the context of a revolution. The Court hinted that the Russian Revolution affected treaties with Russia "by reason of the principle clausula rebus sic stantibus." 49(1) BGE at 195; H. BRIGGs, supra at 932.

24. HARVARD RESEARCH 1045:
Forms of government and constitutional arrangements in these days are constantly

being changed, and if the enjoyment of treaty rights and the duty of performance were dependent upon the continuance of the status quo in respect to the government organization or constitutional system of the parties, one State would never be able to count with certainty on rights which have been promised it by another ....

The statement is amplified if one includes simple changes in government personnel through death and resignation.

25. An argument similar to this is to be found at Harvaso Researcir 1054. The argument is hedged there, however, by the suggestion that rebus sic stantibus might be a ground for permitting revolutions treaty-terminating force.

26. See note 51 infra.

27. Justice Holmes is relevant:

By a side wind what I was saying reminds me of how people in the law as clsewhere

hate to recognize that most questions-I think I might say all Iegal questions-are

questions of degree. I have just sent back an opinion of one of our JJ. with the

criticism of an argument in it of the "where are you going to draw the line" type-

as if all decisions were not a series of points tending to fix a point in a line.

2. Holdies-Pollock IetTers 28 (M. Howe ed. 1941).
} 
corresponds closely to the presence or absence of drastic changes. Other grounds support the distinction between legal and illegal changes of government. A government that came to power by legal means relies for its legitimacy upon the old constitutional authority and is less likely to repudiate treaties created under it. Revolutionary governments, on the other hand, have fewer qualms about repudiating obli* gations assumed by systems that they fought to depose.

The line between revolutions and lesser changes in governments is no more blurred than those found feasible by the law in other areas where the same criteria of continuity and magnitude of change determine whether events are treaty-terminating. A change in territory has not been considered treaty-terminating because no discontinuity accompanies the growth or shrinkage. ${ }^{28}$ And the loose federation of one state with another leaves treaties standing, whereas "true union" terminates them-a distinction based both upon legal continuity and upon the relative magnitude of the changes involved..$^{20}$

Independence and extinguishment are not the only events traditionally recognized as terminating treaty rights and obligations. Treaties may be unilaterally abandoned for several reasons even when no "change of identity" has taken place in either of the parties:

(1) Physical impossibility of performance; ${ }^{30}$

(2) Realization of the purpose of a treaty otherwise than by fulfillment of its obligations; ${ }^{31}$

(3) Violation by a party;32

(4) Desuetude. ${ }^{33}$

In each of these cases circumstances have so changed that the law declines to hold the disadvantaged party to the bargain. The rationale is

28. See notes 11 \& 15 supra.

29. See note 13 supra.

30. OPPENHEIM 945: "All treaties the execution of which becomes impossible subse. quently to their conclusion are thereby rendered void." See Law Commission, art. 58, at 426-28.

31. Oppenheim poses the example of two states which conclude a treaty to get a third state to undertake some course of action. If the third state decides on its own to undertake that course of action, the treaty is said to be realized otherwise than by fulfill. ment of its obligation. OPPENHEIM 945 .

32. The general theory is that violation of an important part of a treaty gives the party wronged an option of unilaterally terminating the treaty, an option which must be exercised within a reasonable time. This covers the majority of cases of violation. Sec McNAiR 553-71 for a discussion of the general theory and its qualifications, and HARVARD ReseARGit 1077-96, which requires certification of the violation by a competent international tri. bunal. McNair thinks the principle is not limited in this way.

33. Ross 222: "It may happen that a treaty is so antiquated that it can no longer be performed or invoked by the parties to it. It is then said to have passed out of 1use or lapsed by desvetudo." See McNAIR 516-18; KeLSEN, supra note 19, at 119-20. 
usually the putative intention of the parties or an implied condition in the treaty. Thus, the ritual runs, although the words of a treaty make no explicit provision for termination or modification in the event of these changes in circumstance, the intention of the parties must surely have done so. ${ }^{34}$ This analysis of such treaty-terminating rules, however, obscures their main thrust, which is not to discover a hidden "intent" of the parties, but rather to set aside agreements when the law concludes it would be unfair to enforce them. The rules are perhaps best regarded as applications of the general principle of international law that treaties must be lived up to rebus sic stantibus s $^{35}$ - so long as circumstances do not change in some way not encompassed by the meaning of the treaty as it would reasonably have been read at the time it was made.

Even if a revolution is not seen as a change of identity sufficient to invoke the treaty-terminating doctrines of the law of state succession, the change of circumstances justifies application of the maxim rebus sic stantibus. This is most obviously true from the point of view of the other party to the treaty. A theocratic state, for example, that enters upon a treaty with another theocracy may fairly regard a revolution which transforms its partner into a communist society as a "vital" change of circumstances-one that should release it from obligations of amity and close cooperation with the other state. This can be stated subjectively (the state did not intend to bind itself to cooperate with

34. See, e.g., note 9 supra; for a discussion of the problems of tacit clauses and presumed intent, see BRIERLY 329-31, and HARVARD RESEARCil 1100.

35. The doctrine is sometimes referred to as the "changed circumstances principle." In Latin, it has two forms: conventio omnis intelligitur rebus sic stantibus and clausula rebus sic stantibus. Its origin is usually traced to Grotius and to Pufendorf, the latter of whom raised the question "whether promises carry with them a tacit condition, provided things remain in the place where they are." Harvard Researcil 1098. The doctrine has obvious analogies to doctrines in the common law of contracts such as frustration or impossibility of performance. Gf. F. Kessler \& Mr. Sharp, Contracts: Cases aNd Mraterlals (1953), chapter 12 of which is subtitled "clausula rebus sic stantibus."

When subjective forms of the doctrine are avoided (sec note 9 supra), attention centers on phrases like "vital changes." See OpPENHErar 938-44. Toolscy, The Unilaleral Termination of Treaties, 20 AM. J. INT'L L. 349-50 (1926), uses both "fundamental" and "vital." The United States Government used the term "essential" when it justified its suspension of the Load Line Convention in 1941, claiming: "It is a well-established principle of international law, rebus sic stantibus, that a treaty ceases to be binding when the bisic conditions upon which it was founded have essentially changed." 40 Ors. ATr.. Ges. 119, 121 (1941). The Load Line Convention, July 5, 1930, 47 Stat. 2228 (1933), T.S. No. 858, was signed in London in 1930 and was eventually ratified by 36 nations; it provided safety limits on loading ships for international voyages. The United States claimed that the existence of war between various parties to the treaty constituted essentially changed conditions.

Some authors have gone so far, in the attempt to avoid the controversy which inevitably surrounds the rebus doctrine, as to deny the doctrine's validity in intcrnational law. See H. KeIsen, Principles of INTERnational Law 358-60 (1952). This, of course, has not lessened controversy, but increased it. See Lauterpacht's discussion of Kelsen's viess on the matter in Book Review, 29 BRrT. Y.B. INT'L L. 512-13 (1952). 
a communist regime) or objectively (the revolution was not a change reasonably foreseeable within the terms of the treaty). However expressed, the principle is that it would be unfair to continue to hold the first state to the treaty, just as it would be unfair to hold it to a treaty the purpose of which had been realized, which had been breached by the other party, or which had lapsed into desuetude.

The revolutionary government itself has perhaps less justification to claim a revolution as an unforeseeable change of circumstance. The change is not forced upon the revolutionary government from outside (as are most of the changes listed supra); further, the revolutionaries may not be able to claim that it was unforeseeable to them when the treaty was concluded. Those who insist, however, that states are the sole subjects of international law, ${ }^{36}$ and that a revolution cannot change the identity of a state should, to be consistent, view a revolution as an upheaval which the state could not properly foresee at the time the treaty was made through its then agent, the pre-revolutionary government.

Ultimately, the change-of-identity and change-of-circumstances treaty termination doctrines both arise from a single equitable principle: a party cannot with fairness be held to an agreement that it has not made. The two separate doctrines merely emphasize different aspects of the principle. The law of state succession stresses the parties-one party cannot be held to an agreement it has not made. The change-of-circumstances rules stress the terms of the agreement-the parties did not agree to perform these acts in these circumstances. The underlying conceptual principle, in both its aspects, supports recognition of revolutions as treaty-terminating events.

II.

The peculiarly weak sanctioning power of international law provides a more pointedly empirical argument that revolutions should be treatyterminating. ${ }^{37}$ As a general proposition, the authority and effectiveness

36. See notes 3 \& 23 supra.

37. It is not denied that international law has sanctions. See, e.g., P. Witd, SANcrions AND TREATY ENForcenent 60-82 (1934), where the following sanctions, among others, are listed and discussed: fear of war or measures of force and reprisal; public opinion; fear of measures of retaliation such as termination of diplomatic relations, cmbargoes, ctc. What is claimed, however, is that sanctions play a significantly smaller role in international law than they do in municipal law. This is the case even though "the great majority of rules of international law are generally unaffected by the weakness of its system of enforcement," due to mutuality of interest in observing such rules. H. Morgentinu, Politics ANono NA. 
of a legal order are undermined by norms with sanctions weaker than the incentives to violate those norms. The inevitable repeated violations destroy respect for the system, and this in turn diminishes the system's ability to affect behavior and to resolve disputes..$^{38}$

All legal systems involve a tension between the power of law to change existing patterns of behavior and its tendency to conform to those patterns. Since the norms of international law depend on such weak sanctions as "international opinion," there is a special pressure for the international legal system to resolve this tension strongly on the side of existing and customary behavior. International law recognizes its own weakness in the stress it places upon custom as a source of its norms. Although most writers distinguish "mere usage" from custom, the two concepts are closely related; ${ }^{30}$ a custom in international law might best be defined as a common state practice of some antiquity, for which a reason may be given. Custom thus is the means whereby international law accommodates the felt needs of states-needs which will be expressed in action. ${ }^{40}$

TIONs 230 (1948). For an interesting perspective on sanctions in the international system, consider these remarks by Thomas Schelling:

Gang war and international war have $a$ lot in common. Nations and outlaws both lack enforceable legal systems to help them govern their affairs. Both cngage in the ultimate in violence. Both have an interest in avoiding violence, but the threat of violence is continually on call. It is interesting that racketeers, as wcll as gangs of delinquents, engage in limited war, disarmament and disengagement, surprise attack, retaliation and threat of retaliation; they worry about "appeasement" and loss of face; and they make alliances and agreements with the same disability that nations are subject to- the inability to appeal to higher authority in the interest of contract cnforcement.

T. SCHELling, The Strategy of Conflict 12 (1960).

38. Domestic law is not entirely free from the infuence of such considerations despite the existence of a central legislative and policing authority. Thus, in America, Prohibition generally serves as an example where divergence from law was so frequent that the whole system was weakened. It would be hard to say that this was not a motivating factor in the repeal of Prohibition.

39. Disputes have arisen over what the distinction between practice and custom is and what is required for a custom to exist. See generally P. COBbETT, 1 CAsES AND OpINioNs ON INTERNATIONAL LAW 5-6 (3d ed. 1909); Kopelmanas, Custom as a Aleans of the Creation of International Law, 18 BRIT. Y.B. INT'L L. 127 (1937); Kunz, The Nalure of Customary Law, 47 AM. J. INT'L L. 662 (1959); MacGibbon, Customary International Law and Aequiescence, 33 BRIT. Y.B. INr'L L. 115 (1957); The Paquette Habana, 175 U.S. 677 (1900); Colombian-Peruvian Asylum Case, [1950] I.C.J. 266; I.C.J. STAT., art. 38, para. 1(b); Anglo-Norwegian Fisheries Case, [1951] I.C.J. 116, 138-39; Case Concerning Rights of Nationals of the United States of America in Morocco, [1952] I.C.J. 176, 199-201.

40. Even Herbert Briggs, who is an articulate foe of using rebus sic stantibus as a legitimate source of treaty termination and who believes that revolutions are not treaty-terminating, notes that " $[t]$ he treaties most likely to be violated are those which, taking no account of the political considerations which sometimes cause States to disregard law, nevertheless attempt to control political conduct by a series of negative or prohibitory rules." H. Bnscas, A Law of Nations 20 (1951). Apparently, it has not occurred to Professor Briggs that the attempt to prohibit treaty termination by a revolutionary government takcs place in
exactly this context. For his discussions of rebus sic stantibus, including criticism of American invocation of the doctrine, see Briggs, The Attomey General Involies Rebus Sic 
Of course, international law cannot always simply approve actual practice without becoming otiose. The existing law must at some time stand firm-even if defied-and serve as a foundation for criticism of the practice. But the law must husband its authority, and expend it with discrimination. Situations where states have the strongest incentive to continue a practice, and where the arguments for proscribing the practice are at best dubious, are not proper occasions for unyielding rigidity. ${ }^{41}$

The doctrine that revolutions leave prior treaties unaffected is a paradigm of the over-ambitious norm. As a matter of practice-a practice now no doubt venerable enough to qualify as a custom-revolutionary regimes renounce those prior treaty obligations which they regard as inconsistent with the aims of their movement. One of the first acts of the 1917 Soviet government, for example, was the unilateral termination of all secret treaties under an announced policy of opening up foreign affairs to the control of the people. ${ }^{42}$ Righteous denunciation of such moves as "violations of international law" can have little effect on revolutionaries. The new leaders have overthrown a domestic legal system supported by force; they are unlikely to respond to the

Stantibus, 36 AM. J. INT'L L. 89 (1942), and Briggs, Rebus Sic Stantibus Before the Security Council: The Anglo-Egyptian Question, 43 AM. J. INT'L L. 762 (1949).

41. McDougal \& Lans, supra note 2, at 341-43 take note of likelihood of "evasion" of treaties as a reason for recognizing the legitimacy of rebus sic stantibus in certain instances. They compare rebus sic stantibus to the concept of "changing neighborhood conditions" in property law, a concept used to modify perpetual restrictive covenants, and go on to argue: "A rule against perpetuities is as necessary in international jurisprudence as in the law of property, and failure to give such a doctrine effective implementation is fratught with far more serious consequences. Complete resolution of the conflict between the necd for change and the desirability of preventing unilateral action in transgression of inter. national obligations is obvously dependent upon the establishment of an international tribunal with jurisdiction to consider pleas that provisions in treaties or agrcements have become outmoded.

"In the absence of any recognized international tribunal, capable of enforcing its decrecs, almost all nations have found it appropriate or necessary on occasion to invoke the maxim unilaterally. Whatever the logical tergiversations of professed scholars in the ficld of international law, statesmen have readily recognized that the doctrine, although potentially dangerous, has played an invaluable function." The authors then go on to argtic that executive agreements are no more susceptible to "evasion" than treaties.

42. Such treaties were abrogated only "in so far as they tend to the augmentation of the profits and privileges of Russian capitalists." Korovin, supra note 17, at 762 (citing a decree by the Second All-Russian Congress of Soviets in 1917). The sume statement is cited at TRISKA \& SLUSSER 142 in a slightly different form. It is interesting to note that the Russian revolutionaries never chose to abrogate all treaties. See HARvARD REsEARc11 1119.

An example of a treaty between the United States and China which was broken after the Chinese revolution is the Treaty of Friendship, Commerce and Navigation, Nov. 4, 1946, 63 Stat. 1299, T.I.A.S. No. 1871. Among other things, the treaty provides, in art. 4, for the right of citizens of each state to own corporations in the partner state.

United States dissatisfaction with Guba has resulted chiefly from expropriation of pri. vate investment, rather than abrogation of treaties. See Domke, Foreign Nationalization, b5 AM. J. INT'L L. 585 (1961). For further discussion, see Montague, $A$ Brief Study of Some of the International Legal and Political Aspects of the Guantanamo Bay Problem, 50 Kx. L.J. 459 (1962). 
watery sanctions of an international legal system which attempts to impose upon them the expressed will of the regime they have just deposed.

The doctrine that revolutions do not affect treaties, far from encouraging good international behavior, will antagonize revolutionary regimes that view the doctrine as an expression of support for the previous regime. This irritation, when added to the trouble revolutionary regimes inevitably have in achieving recognition from existing powers, ${ }^{43}$ can alienate them from the international legal system-a system they might otherwise be willing to join. ${ }^{44}$ The antagonized revolutionary government will then less readily form the habit of justifying its actions under international law; yet the virtual universality of this habit, however disingenuously it is sometimes followed, is one of the few strengths of international law..$^{45}$

43. A State Department memorandum of 1958, justifying United States policy on the recognition of China, serves as a good example of the interconnection between treaty termination regarded as illegal and a decision to withhold recognition. After suggesting that the Chinese Communist Party is a "tiny minority" holding the Chinese people in check by "brutal repression," the memorandum goes on to say:

Finally, it has shown no intention to honor its international obligations. One of its first acts was to abrogate the treaties of the Republic of China, except those it chose to continue.

U.S. Policy on Nonrecognition of Communist China, 39 Dep'T StATE BuLL. 385, 388 (1958). Earlier, at a press conference on Oct. 12, 1949, Secretary of State Dean Acheson had highlighted the importance of treaty performance by making it one of his three tests of recognition, which were:

(I) that [the Chinese Communist government] control the country that it claimed to control;

(2) that it recognize its international obligations; and

(3) that it rule with the acquiescence of the people who were ruled.

Cited in Jessup, U.S. Policy Toward China, 1949-50, 25 Dep'T STATE Burt. 603, 605 (1950). Still earlier, on 26 Jan. 1949, one member of the Department expressed his apprehension over treaty-termination and his view of it:

We cannot imagine that Chinese Communists would wish to become, like Hitler,

avowed treaty breakers. Treaties should be abrogated only under their own provisions or by mutual consent.

Cabot, An American Answer to Chinese Communist Propaganda, 20 DEx'T Stare BuLl. 179, 182 (1949) (reprint of speech at the American University Club in Shanghai).

44. This willingness to join is evidenced in the great pains to which revolutionary governments have gone in the past to justify treaty termination under international law. Two examples will serve. At the Genoa Conference in 1922 the Soviet Union was cxceedingly careful to defend its actions under what it felt was existing international law. Tnusfa \& SLusser 390. The Chinese justification has taken the form of two developed doctrines: (l) that unequal treaties are invalid, and (2) that a revolution is a changed circumstance. For citation to the Chinese arguments in one context and for discussions of them, see Sharma, The India-China Border Dispute: An Indian Perspectiv'c, 59 Am. J. INT'L I. 16 (1965).

45. An analysis similar to that given in the text is contained in Kopelmanas, Custom as a Means of the Creation of International Law, 18 BRrT. Y.B. INT'. L. 127 (1957). Kopclmanas first establishes that the internal organs (legislatures, courts, ctc) of a state can serve as sources of international law by adopting regular practices, practices which become international law through the concept of custom. He argues that these uniform practices are the result of certain internal social needs and that "the formation and cxistence of a custom depend on its conformity with the social needs of a legal order." Id. I48. He goes on to assert, moreover, that "[t] he customary rule will be certain and efficacious in proportion to the urgency of the needs to be satisfied. ... If the difference between the necessary' solu- 
III.

Revolution is not a well-defined concept in international law, so if revolutions are to terminate treaties, criteria by which they can be identified must be found. The reasons developed here for granting revolutions treaty-terminating force have stressed two characteristics: a radical change in national policies and identity, and the lack of "legal continuity" between the old and the revolutionary regimes usually accompanying such policy upheavals. ${ }^{40}$ The legal discontinuity normally occurs in a transfer of state power by means of the use or threat of organized coercion; ${ }^{47}$ the changed policies are usually manifest in fundamental changes in social, economic, or political institutions.

"Legal discontinuity" alone might arguably be a sufficient test for the termination of treaties. ${ }^{48} \mathrm{~A}$ regime that came to power by unconstitutional means might be thought likely to violate the treaties of its predecessor, and might also be thought unfairly held to the obligations taken on by that predecessor. But a rule such as this would grant treatyterminating force to every coup d'etat in which one dictator illegally replaced another; although such changes of power are often accompanied by no significant alterations in social or economic institutions, or in international alignments. ${ }^{40}$ When nothing changes but the brass

tion and the actual legal solution is too great, the insufficiencies of the law in force will always end by bursting the dikes by which law seeks to restrain the normal cvolution of human relationships." Id. 150.

Our argument in the text is that the dikes in international law are especially thin and that the motives which valid treaty-terminating changes generate for violation of cxisting treaties are especially strong. Accordingly, any discussion of what lies at the foundation of the rebus sic stantibus doctrine must take account of whether the change in question increases the likelihood of treaty violation.

46. The literature on revolutions is vast. Some of the more recent and well-known works include H. ARENDT, ON REvolution (1963); C. BRINTON, THE ANATOMY of Revolv. TION (rev. ed. 1952); E. HobsBawm, THE AGE OF REVolution, Europe 1789.1848 (1962); Meusel, Revolution and Counter-Revolution, 13 ENCYCLOPAEDIA OF THE SOCIAL ScIENCES 367 (1934); Revolution (C. Friedrich ed. 1966). Revolution, of course, is of importance for more reasons than its effect on treaties. It tends to be injected into discussions of whether it is ever right to disobey the law, for instance. For a discussion which separates the two questions and which raises difficulties in the concept of a revolution, see Wasscrstrom, The Obligation to Obey the Law, 10 U.C.L.A. L. REv. 780 (1963).

47. The case for making actual violence a part of the definition is put by C. TiLlY \& J. Rule, Measuring Political Upheaval 6-7 (1965). They argue that violence insures the seriousness of the movement it is associated with, is extraordinary when not surrounded with official ceremony, and is easy to identify. Violence will probably be a part of every revolution, but it seems wise to leave open the possibility of a well-planned, bloodless transfer of power which is coercive and which results in fundamental changes. Sce Macpherson, Revolution and Ideology in the Late Twentieth Century, in Revolurion 139, 140 (C. Friedrich ed. 1966), for a definition similar to that used here.

48. See the discussion of Kelsen's theories, note 19 supra.

49. Some authors think that a coup is a revolution in law but not in politics. See H1. ARENDT, ON REVOLUTION 27 (1963). 
name plates it seems unfair to treaty partners to license the abrogation of treaties which may be disadvantageous only for reasons unrelated to the coup itself. Moreover, to the extent national policies are unaltered, the new junta will demand a fresh slate less urgently and will be correspondingly less willing to defy international law.

Rejecting blanket treaty termination in every case of illegal transfer of state power leaves the difficult task of identifying "radical" changes of policy and "fundamental" changes in institutions. Revolutionary change may be like hard-core pornography: one knows it when one sees it. ${ }^{50}$ Russia, China and Cuba have undergone revolutions in the twentieth century, as have Mexico, Turkey, Egypt, Italy and Spain. ${ }^{61}$ In identifying revolutions, international law, ill-equiped to make sophisticated judgments of social fact, must rely largely upon the announced program of putative revolutionary regimes, and upon formal and explicit changes made in institutions of government and society. For treaty purposes, changes in international alignment will be particularly important in identifying true revolutions. Internally, changes in form of government, redistribution of wealth (including land re-

50. Cf. Jacobellis v. Ohio, 378 U.S. 184, 197 (1964) (concurring opinion of Stcwart, J.).

51. Without making a thorough historical analysis, it may reasonably be asserted that the seven major powers of the world have experienced at the very most ten revolutions in the last two hundred years. (Oppenheim claims that intemational law began as carly as the seventeenth century. OPPENHEIMr 6.) Taking the seven major powers may distort things since their place in the world today may be at least partially due to their political stability, but on the other hand most treaties involve these countries.

1. China. Most observers count two revolutions, the first commencing in 1911 and eventually establishing Chiang Kai-shek, the second culminating in 1949 and establishing Mao Tse-tung.

2. France has had one to four revolutions-the great revolution of 1789 , commonly called simply "the French Revolution"; the July revolution of 1830, establishing the July Monarchy; the revolution of 1848, establishing the Second Republic, which lasted until 1852; and the revolt of 1871 giving rise to the Paris Commune and culminating in the Third Republic.

3. Since Germany was unified under William $I$ and Bismarck, it has had one ostensible revolution: the establishment of the Weimar Republic. This was caused, hoverer, by Germany's position in the War and Allied refusal to bargain for peace with the Kaicer. The issue is also moot for treaty termination purposes in that the War had already terminated most of Germany's treaties.

4. Japan's Meiji Revolution of 1868 overthrew the feudal shogunate and brought back the emperor, while it also opened the country to westem infuence. Since the Mreiji Revolution never really broke the back of the large feudal interests, some have been reluctant to call it a revolution at all.

5. Russia. The end of the Romanoff dynasty and the establishment of the Ferensty; government in 1917 was certainly a revolution. The October Revolution of 1917 in which Lenin seized power was probably a second revolution, the decision turning on a greater comparison of the policies of the two governments than is possible here.

6. The United Kingdom has had no revolutions since the serentcenth century, and there is some dispute over whether it had any then, either in 1688 or 1640 .

7. The United States achieved its independence through revolution in 1776.83. For treaty termination purposes, however, this determination would be irrelevant since independence automatically terminated all treaties.

See W. LANGER, AN ENcYclopediA OF WORLD History (3d rev. ed. 1963). 
form), and obvious shifts in power between social classes-particularly when carried out through formal legislation, and when made in the name of the revolution-will be objective indicia of revolution.

There will, of course, be close cases: where governments claim revolutionary status for themselves or their treaty partners to justify treaty abrogation, and where but a few of the typical characteristics of revolution are present. In such cases, a presumption should run in favor of a regime's characterization of itself. If its initial pronunciamentos stress continuity with the past, despite minor illegalities in its path to power, the new regime shows itself amenable to appeals for stability based upon other states' relations with its predecessor. Of course, that amenability cannot well be preserved unless its partners as well are held to prior treaties. Where a new government stresses its clean rupture with the past and parades the evils of its predecessor to justify the revolt, it is likely to disregard and resent accusations of violating in. ternational law. Therefore, neither it nor its partners should be held to prior agreements.

IV.

The remaining question is which treaties should revolutions terminate. Revolutions clearly should affect only treaties which establish a continuing relationship-treaties which can, in some sense, be "terminated." A revolutionary government can hardly expect to take back an exchange of goods by treaty executed years before. Similarly, treaties of cession typically deprive the ceding state of "all interests" in the territory. People who live in the territory or who have moved into it after the cession have a reliance interest in the control of the new sovereign, and it is difficult to find any justification for a revolutionary government's overriding this interest. Treaties settling disputed boundaries are conceptually and functionally the same as treaties of cession; they, too, create permanent expectations on the part of individuals who settle in land on one side or another of the agreed boundary. ${ }^{52}$

Other treaties, sometimes called constitutive treaties, may through time come to be recognized as part of international law binding states not signatory to the treaties..$^{53}$ The treaty concluded at the Congress

52. See, e.g., Sharma, supra note 44.

53. Under I.C.J. STAT. art. 38, para. 1(a), the International Court of Justice is permitted to apply "general or particular" treaties as international law. Treaties have always been regarded as a source of international law, extending beyond the legal relationships of the treaty partners to the rest of the legal system. This is especially clear when the treaty is a multi-nation pact on some important issue in international law. It is also true, 
of Vienna in 1815 conferring neutral status upon Switzerland, for example, is thought by most nations to "possess universal validity." Since such treaties are a feature of the international order independently of the actions of the predecessor regime, they should not be terminated by revolutions.

Two approaches are possible to the remaining bulk of treaties, the so-called "personal treaties" between nations. ${ }^{55}$ The first approach would involve close examination of the interests affected by the treaty and a case-by-case comparison of those interests with the particular changes of policy proposed or effected by the revolutionary government. Thus, a revolution which altered the political structure of a state might have little effect upon its commercial interests." Under this approach, only treaties premised upon the former political structure would be terminated by the revolution, while commercial treaties would be unaffected. Ideally, this approach would best serve the princi-

however, of bilateral treaties, particularly if a great many exist on a particular topic of concern. Thus, in 1958, the U.S. State Department said: "It is acoepted legal doctrine that the existence of customary rules of international law, i.e., of practices accepted as law, may be inferred from similar provisions in a number of treaties." Dep't OF STate, MfesionuNdum

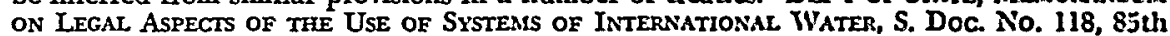
Cong., 2d Sess. 63 (1958). Briggs rejects the distinction between purcly contractual treaties and law-making or constitutive treaties, arguing that both can be sources of international law. Briggs, supra note 40, at 47-48. See also Bishop 31-35. For use of the tcrm "constitutive" and a discussion of the distinction, see MCNAIR 259-71, 739-52. The Sovict vicw is outlined at TRISKA \& SLUSSER 100-05.

Multipartite treaties present special problems in certain instances. Sec, c.g., Jenks, State Succession in Respect of Law-Mraking Treaties, 29 Brur. Y.B. InT'L L. 105, 140 (1952): "The effect of changes in international status on obligations under multipartite instruments of a legislative character is . . . still an open question."

54. MCNAIR 260.

55. The typical treaty between two nations is sometimes referred to as a "personal" treaty and is very much like a contract in private law. Such treaties may be classified into four rough categories, some of which overlap to an extent. First, there are treaties which primarily concern the political relations of a state: examples are treaties of friendslip, neutrality, formal alliance, and non-aggression. Second, there are treatios which establish relations of a commercial or economic nature: examples are treaties dealing with tarifts, exchange of goods and services, subsidies, and reciprocal bilateral arrangements on navigation rights, entry and travel of nationals of the partner, and registration of com. panies and patents. Third, there are administrative treaties: examples are treaties which regulate the mail, contraband, drugs, and treaties which provide for the protection of people who travel in the partner's territory. Finally, there are treaties which may be called judicial: examples are treaties providing for extradition and treatics concerning the effect of foreign judgments. See generally MaNAIR 739-54.

56. Oddly enough, McNair takes the view that politial trenties are not subject to "... any looser practice in regard to ... binding force," id. 501, yet couples with this the apparently quite radical view that for commercial treatics ". . . the existence of an implied right of denunciation upon giving reasonable notice can readily be inferred from the very nature of the treaty on the ground that it requires revision from time to time in order to bring it into harmony with changing conditions," id. 504. (In support of this latter proposition he cites the fact that commercial treaties between Great Britain and Germany were not revived by the conclusion of the First World War and the fact that there is a growing practice to include denunciation clauses in commercial treaties.) If the practice in regard to political treaties is at least as "loose" as that in regard to commercial treaties, then it would seem Lord McNair has proposed a vicw which rould accom- 
ples of fairness, preserving stability of expectations, and avoiding unenforceable norms. But the approach would lack clarity and certainty, and these virtues are crucial in international law, which is not enforced by authoritative tribunals able to decide close cases but by states responsible only to themselves. In practice, revolutionary governments will often abrogate treaties. Inevitably, disputes will arise from such actions, and the issues on which such disputes can be raised should be minimized. A rule based upon close scrutiny of the "purposes" or "effects" of revolutions raises the spectre of one state arguing with another about the minutiae of the doctrine or the achievement of the latter's revolution.

The second, and preferable, approach would depend only upon the determination that a revolution had in fact occurred. After a revolution, the revolutionary state and its treaty partners would have the option to terminate any treaties between them. ${ }^{67}$ This approach is not without its costs. It will allow states which find treaties disadvantageous for reasons unrelated to the revolution to abrogate them without the condemnation of international law. ${ }^{58}$ It has the great advantage, nevertheless, of narrowing possible disputes over the legitimacy of termination to a single relevant and relatively manageable issue-whether a revolution has in fact occurred.

V.

Practical administration of treaty termination after revolution requires that an effective procedure be devised. Writers on international law, always wary of unilateral treaty termination, have called the problem of procedures for effecting the rebus sic stantibus concept "perhaps the thorniest problem in the entire law of treaties." ${ }^{50}$ But once treaty

plish almost everything argued for here; and it becomes difficult to to understand his reluctance to assert that revolutions are treaty-terminating. It may be, however, that he is asserting that political treaties are less subject to changing conditions than are commercial treaties. See McNaIR 501-05.

57. Apart from executed and constitutive treaties.

58. "It is always a doubtful course, to argue against the use or existence of a power, from the possibility of its abuse." Martin v. Hunter's Lessee, 14 U.S. (1 Wheat.) 141, 159 (1816).

59. McDougal \& Lans, supra note 2, at 339. The rest of the quotation is instructive: "Great diversity of opinion has been expressed by writers on the subject, with many taking the position that the principle of rebus sic stantibus is untenable. Possibly this antipathy stems from the fear that the doctrine, once admitted into the House of International Law, would provide a convenient rationalization for constant unilateral denunciation of treaties. Yet it is clear that an attempt to endow agreements with eternal life is foredoomed to failure and, even in those cases where it could be imposed on weak powers by force or threats, would be unjust." Id. 339-40. (The reference to "eternal life" weakens the force of the statement somewhat since rebus sic stantibus concerns more than terminating 
termination after revolution has been recognized as an occasion for the conformity of international law to international practice, the prob. lem simplifies itself; the problem then is merely to ensure that the abrogating party has taken good faith steps to achieve agreement with its partner before it ends its treaty obligations unilaterally.

The problem is no different in the case of revolution than in the case of other treaty-terminating changes, and procedures devised to effect rebus sic stantibus terminations can apply as well to revolutions. One such procedure is based upon that in the Harvard Research Draft Convention on the Law of Treaties. ${ }^{.0}$

First, a state desiring termination must notify its treaty partner of that intent, either through normal diplomatic channels or, where normal channels are disrupted, in another effective way. Next, the parties may explore any of three methods for bilateral termination or modification of the treaty: first, agreement of the parties both on the actual occurrence of a revolution and on termination or modification of the treaty; second, referral to an agreed arbitrator for decision on those issues; and third, submission of the issue to an international tribunal to which both states have previously given general jurisdiction (unless one or the other of the states withdraws itself from such jurisdiction on a permanent basis). Only after these three methods have proved unsuccessful may either state unilaterally terminate the treaty. The treaty is suspended, however, until a decision on its fate is reached. ${ }^{61}$

ancient treaties, but the spirit of the statement is clear and the cxamples which follow suggest a wider scope.)

60. HARVARD Research, art. 28, at 1096. The procedure there provides for suspension of the treaty during negotiations. This is also a requirement of the procedure set out infra here.

61. Two final matters: (1) Compensation may in some cases be appropriate. For a discussion of the existing rules regarding expropriation, sce Domke, supra note 42. It is sug. gested that the best rule in the context of treaty termination upon a revolution vould be that the treaty partner is to pay the cost to his partner or the value to him, whicherer is lower, unless such a sum would be unreasonably or unjustly high. (2) Some period of prescription seems desirable on the right of a partner to terminate; five jears is suggested. 